\title{
BSH-CP based 3D solid-state NMR experiments for protein resonance assignment
}

\author{
Chaowei Shi - Hannes K. Fasshuber • Veniamin Chevelkov • \\ Shengqi Xiang • Birgit Habenstein · Suresh Kumar Vasa • \\ Stefan Becker · Adam Lange
}

Received: 8 November 2013/ Accepted: 20 January 2014/Published online: 1 March 2014

(C) Springer Science+Business Media Dordrecht 2014

\begin{abstract}
We have recently presented band-selective homonuclear cross-polarization (BSH-CP) as an efficient method for CO-CA transfer in deuterated as well as protonated solid proteins. Here we show how the BSH-CP $\mathrm{CO}-\mathrm{CA}$ transfer block can be incorporated in a set of threedimensional (3D) solid-state NMR (ssNMR) pulse schemes tailored for resonance assignment of proteins at high static magnetic fields and moderate magic-angle spinning rates. Due to the achieved excellent transfer efficiency of $33 \%$ for BSH-CP, a complete set of 3D spectra needed for unambiguous resonance assignment could be rapidly recorded within 1 week for the model protein ubiquitin. Thus we expect that BSH-CP could replace the typically used $\mathrm{CO}-\mathrm{CA}$ transfer schemes in well-established 3D ssNMR approaches for resonance assignment of solid biomolecules.
\end{abstract}

Keywords Solid-state NMR · Magic-angle spinning · $\mathrm{BSH}-\mathrm{CP} \cdot$ Protein resonance assignment · Ubiquitin

Electronic supplementary material The online version of this article (doi:10.1007/s10858-014-9820-8) contains supplementary material, which is available to authorized users.

C. Shi · H. K. Fasshuber · V. Chevelkov · S. Xiang ·

B. Habenstein · S. K. Vasa $\cdot$ S. Becker $\cdot$ A. Lange $(\square)$

Department of NMR-based Structural Biology, Max Planck

Institute for Biophysical Chemistry, Am Fassberg 11,

37077 Göttingen, Germany

e-mail: adla@nmr.mpibpc.mpg.de

C. Shi

School of Life Sciences, University of Science and Technology of China, 96 JinZhai Road, 230026 Hefei, People's Republic of China

\section{Introduction}

Magic-angle spinning (MAS) solid-state NMR (ssNMR) has evolved in the past decade into a powerful technique to determine structure and dynamics of insoluble proteins (Goldbourt 2013; Knight et al. 2012; Sengupta et al. 2012) and protein complexes (Mainz et al. 2013), such as amyloid fibrils (Tycko 2011; Wasmer et al. 2008), membrane proteins (Hong et al. 2012; Ullrich et al. 2011) and oligomeric assemblies (Jehle et al. 2010; Loquet et al. 2012). This became possible in part due to the availability of higher external magnetic fields and the development of twodimensional (2D) and three-dimensional (3D) homonuclear and heteronuclear correlation experiments.

The sequential resonance assignment is the basis of all further ssNMR spectroscopic studies (Pauli et al. 2001; Schuetz et al. 2010; Shi et al. 2009; Sperling et al. 2010). An important step was the development of efficient ${ }^{15} \mathrm{~N}-{ }^{13} \mathrm{C}$ SPECIFIC-CP transfer which is widely used today (Baldus et al. 1998). Another crucial part in many protein sequential assignment schemes is the magnetization transfer between $\mathrm{CO}$ and CA nuclei. Here, a number of recoupling techniques have been employed so far, with the most widely used methods being proton-driven spin diffusion (PDSD) (Dusold and Sebald 2000), DARR/RAD (Morcombe et al. 2004; Takegoshi et al. 2001), MIRROR (Scholz et al. 2008) and DREAM (Verel et al. 2001). At stronger external magnetic fields, higher MAS frequencies are preferable for efficient CSA suppression to minimize spinning sidebands. Under these conditions (high field of 700-900 MHz, moderate MAS rate $\sim 20 \mathrm{kHz}$ ), PDSD, DARR and MIRROR become less efficient due to an increased Zeeman energy difference and better averaging of dipolar couplings. The DREAM scheme works well when the spinning rate considerably exceeds the isotropic 
chemical shift difference of CO and CA spins (Laage et al. 2008; Vijayan et al. 2009), and thus it is more suitable for small rotor sizes with small active sample volume, which may not be favorable if enough sample is available to fill larger rotors (e.g. $3.2 \mathrm{~mm}$ outer diameter) (Demers et al. 2011).

Recently, robust and efficient band-selective homonuclear (BSH) cross-polarization between $\mathrm{CO}$ and CA spins was achieved by us in both highly deuterated (Chevelkov et al. 2013a) and protonated protein samples (Chevelkov et al. 2013b). The most efficient recoupling is achieved when the sum of effective radio-frequency fields on $\mathrm{CO}$ and $\mathrm{CA}$ resonances equals two times the spinning frequency, yielding up to $50 \%$ of magnetization transfer efficiency in highly deuterated proteins and $33 \%$ in protonated proteins. This compares very favorably to PDSDtype experiments which are often applied. Furthermore, different from the second-order PDSD/MIRROR phenomena, BSH-CP employs a first-order recoupling effect and undesired sequential or long-range magnetization transfers are suppressed (Chevelkov et al. 2013b; Hodgkinson and Emsley 1999).

Herein, we apply BSH-CP in a complete set of 3D protein sequential resonance assignment experiments, namely NCOCA, NCOCACB, and NCACO in addition to standard 3D NCACB and CANCO experiments. Using a set of the resulting five $3 \mathrm{D}$ spectra, reliable and unambiguous assignments can be obtained. Additionally, we discuss results from a $3 \mathrm{D} \mathrm{N}(\mathrm{co}) \mathrm{CACB}$ spectrum which could be useful to assign larger proteins.

\section{Results and discussion}

\section{Comparison of BSH-CP, MIRROR and DARR for CO-} CA transfer

Previously, we compared in detail the performance of BSH-CP and PDSD CO-CA transfers in 1D and 2D experiments (Chevelkov et al. 2013b). Here, we compared the performance of BSH-CP with the performance of MIRROR and DARR in NCOCX experiments. Figure 1 shows $1 \mathrm{D}{ }^{13} \mathrm{C}$ spectra obtained with BSH-CP NCOCA and NCOCX experiments based on MIRROR recoupling. The contact time of the BSH-CP step was $4.0 \mathrm{~ms}$. The recoupling time for $\mathrm{CO}-\mathrm{CA}$ transfer during MIRROR was $30 \mathrm{~ms}$, which yields maximal CA signal. Panel b presents the dependence of $\mathrm{CO}-\mathrm{CA}$ transfer on the employed ${ }^{1} \mathrm{H}$ $\mathrm{CW}$ recoupling RF field in the NCOCX experiment based on MIRROR and DARR recoupling. The maximum transfer rate was achieved with a proton field strength of $16 \mathrm{kHz}$, which corresponds to the MIRROR, $n=2$ condition. The magnetization transfer efficiency at a proton RF (a)

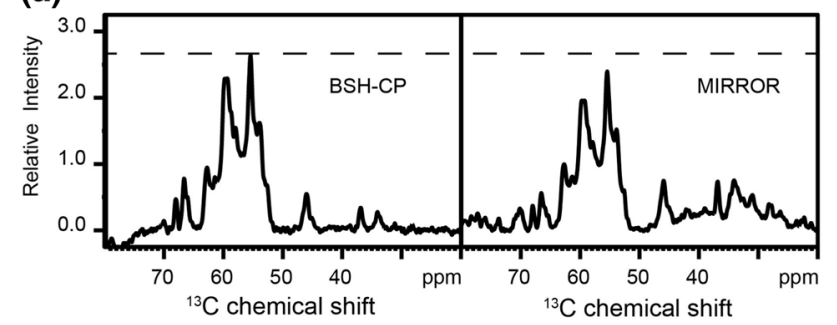

(b)

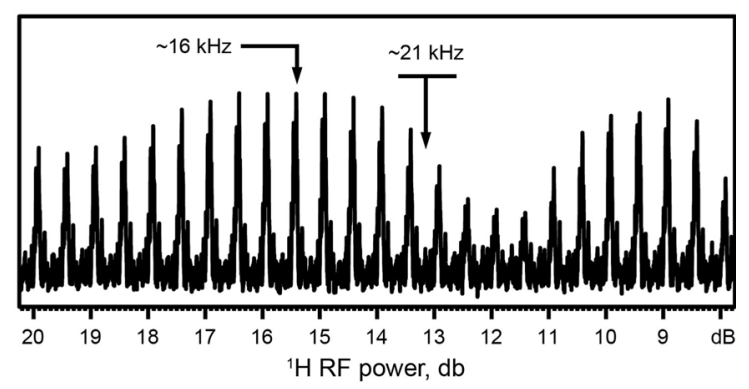

Fig. 1 a CA intensity after CO-CA transfer in BSH-CP based NCOCA and MIRROR based NCOCX experiments as indicated in the panels. The duration of the BSH-CP step was $4.0 \mathrm{~ms}$, while the MIRROR contact time was $30 \mathrm{~ms}$ with a ${ }^{1} \mathrm{H}$ RF field strength set to $16 \mathrm{kHz}$. b CA signal after CO-CX magnetization transfer in a MIRROR/DARR based NCOCX experiment as a function of the applied ${ }^{1} \mathrm{H}$ RF field strength. The contact time was $20 \mathrm{~ms}$. Experiments were recorded on a $850 \mathrm{MHz}$ wide-bore spectrometer at an MAS rate of $21 \mathrm{kHz}$

field strength of $21 \mathrm{kHz}$, which corresponds to DARR, was extremely low at the given experimental conditions. The $\mathrm{CA}$ amplitude in the BSH-CP NCOCA experiment is ca. 1.12 times higher than in the MIRROR NCOCX experiment. Additionally, MIRROR is based on a second-order recoupling effect and facilitates long range magnetization transfers as well, which are not desirable in assignment experiments. In contrast, BSH-CP employs a first-order recoupling mechanism and unwanted sequential $\mathrm{CO}-\mathrm{CA}$ and CA-CA transfers are efficiently suppressed by dipolar truncation.

\section{Design of BSH-CP based 3D pulse schemes}

The general pulse schemes for the collection of threedimensional (3D) NCOCA, NCOCACB and NCACO spectra are presented in Fig. 2.

Initial ${ }^{1} \mathrm{H}_{-}{ }^{15} \mathrm{~N}$ magnetization transfer is achieved by cross polarization at the $n=1$ Hartmann-Hahn condition. During the subsequent ${ }^{15} \mathrm{~N}$ indirect evolution period, a hard $180^{\circ}$ pulse is applied on the carbon channel to refocus ${ }^{15} \mathrm{~N}-{ }^{13} \mathrm{C}$ scalar couplings. Next, a double quantum (DQ) SPECIFIC-CP step is used for the ${ }^{15} \mathrm{~N}-{ }^{13} \mathrm{C}$ transfer (Baldus et al. 1998; Vijayan et al. 2009), followed by ${ }^{13} \mathrm{C}$ indirect evolution where another hard $180^{\circ}$ pulse is applied on the nitrogen channel. 
(a) NCOCA

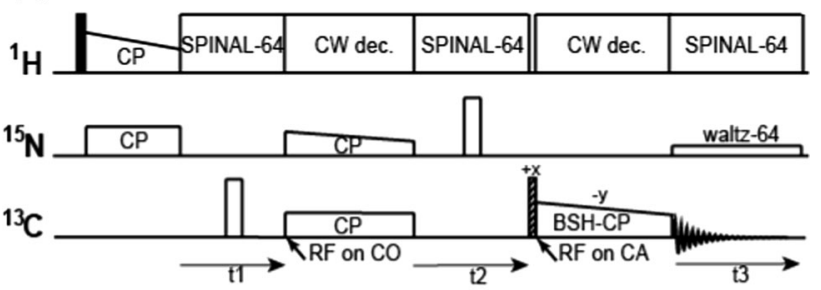

(b) NCOCACB

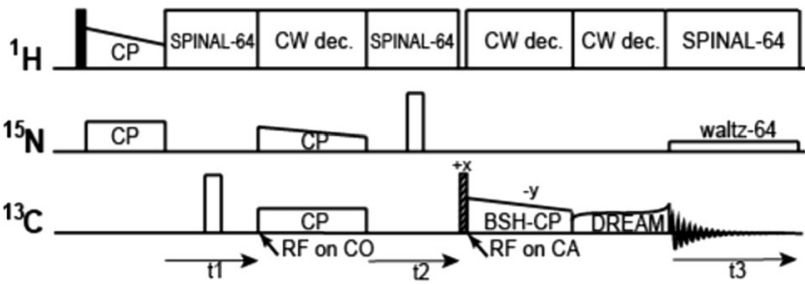

(c) NCACO
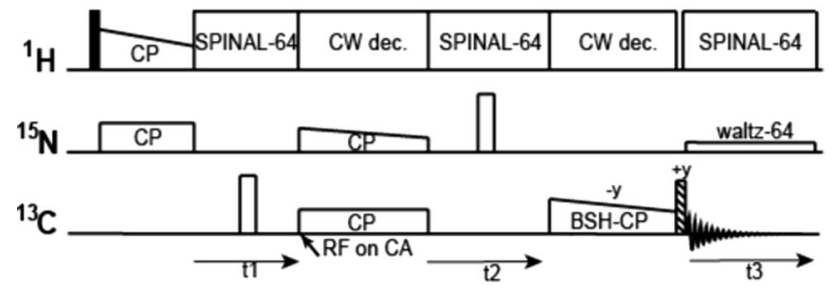

Fig. 2 The general pulse sequences for a 3D NCOCA, b 3D NCOCACB and c 3D NCACO correlation experiments based on band-selective homonuclear (BSH) $\mathrm{CP}$ transfer between $\mathrm{CO}$ and $\mathrm{CA}$ bands. Open, filled and striped bars represent hard $180^{\circ}, 90^{\circ}$ and trim pulses, respectively. The pulse scheme for the $3 \mathrm{D} N($ co)CACB experiment which is a straightforward modification of the NCOCACB experiment can be found in Figure S1 (Supporting Information)

Homonuclear polarization transfer between $\mathrm{CO}$ and $\mathrm{CA}$ is achieved using the previously described BSH-CP transfer. Due to the fact that the chemical shift variation in the $\mathrm{CO}$ band is smaller than in the CA band, it is optimal to apply the RF irradiation in the middle of the CA region in order to avoid a too narrow banded transfer (see detailed explanation in ref. (Chevelkov et al. 2013a)). The theoretical RF field amplitude $\omega_{r f}$ is given by:

$\sqrt{\Omega^{2}+\omega_{r f}^{2}}+\omega_{r f}=2 \omega_{r}$

where $\Omega$ is the CO chemical shift offset and $\omega_{r}$ the spinning frequency. For $\mathrm{CO}$ to $\mathrm{CA}$ magnetization transfer, the $\mathrm{CO}$ magnetization is flipped to the effective field by a hard trim pulse before BSH-CP (see Fig. 2 a, b). The flip angle $\theta$ is given by:

$\theta=90^{\circ}-\arctan \left(\omega_{r f} / \Omega\right)$

For $\mathrm{CA}$ to $\mathrm{CO}$ magnetization transfer, a trim pulse is applied after BSH-CP, in order to bring the $\mathrm{CO}$ magnetization back to the transverse plane without affecting the CA magnetization (Fig. 2c).

In the $2 \mathrm{D}$ version of the NCOCA experiment (Chevelkov et al. 2013b) (dimension 1: N; dimension 2: CO, CA) it is important to maximize the $\mathrm{CO}$ signal by bringing it back to the transversal plane before detection by means of a second trim pulse after the BSH-CP part. In the $3 \mathrm{D}$ version (dimension 1: $\mathrm{N}$; dimension 2: $\mathrm{CO}$; dimension 3: $\mathrm{CA}$ ) the $\mathrm{CO}$ signal is already recorded in the 2nd dimension. Applying a trim pulse will thus only affect the diagonal N$\mathrm{CO}-\mathrm{CO}$ peaks but not the real 3D N-CO-CA cross-peaks of interest.

Homonuclear polarization transfer from $\mathrm{CA}$ to $\mathrm{CB}$ in the NCOCACB experiment (see Fig. 2b), utilizes DREAM recoupling (Verel et al. 2001). SPINAL-64 decoupling (Fung et al. 2000) is applied on the proton channel during direct and indirect isotropic chemical shift evolution periods, and WALTZ-64 decoupling (Shaka et al. 1983) is applied on the nitrogen channel during detection to remove heteronuclear couplings. Continuous wave decoupling is applied on the proton channel during the SPECIFIC-CP, BSH-CP and DREAM transfer steps, respectively.

Application to MPD-crystallized ubiquitin and assignment strategy

As a first application of our 3D BSH-CP based experiments to resonance assignment, 3D NCOCA, NCOCACB, NCACO, and also standard 3D NCACB and CANCO spectra of MPD-crystallized uniformly $\left[{ }^{13} \mathrm{C},{ }^{15} \mathrm{~N}\right]$-labeled ubiquitin were recorded at $20 \mathrm{kHz}$ MAS on an $800 \mathrm{MHz}$ standard-bore spectrometer. Due to the combined effect of very efficient N-CO SPECIFIC-CP transfer at $20 \mathrm{kHz}$ MAS (compared to low MAS rates $\sim 11 \mathrm{kHz}$, see ref. (Chevelkov et al. 2013b)) and the high CO-CA transfer efficiency achieved using BSH-CP (33\%), the complete set of five 3D spectra could be recorded in 1 week with $3 \mathrm{~s}$ pre-scan delay (see Table 1) and the resulting spectra exhibit excellent sensitivity and resolution. A sequential walk along the backbone resonances can be easily obtained from a combination of all of these five spectra. A strip-plot showing the assignment procedure for a five-amino acid stretch is presented in Fig. 3.

Inter-residue spin system resonances $\left(\mathrm{N}_{\mathrm{i}}, \mathrm{CA}_{\mathrm{i}-1}, \mathrm{CB}_{\mathrm{i}-1}\right.$, $\mathrm{CO}_{\mathrm{i}-1}$ ) could be determined from 3D NCOCA and NCOCACB spectra, while intra-residue spin system resonances $\left(\mathrm{N}_{\mathrm{i}}, \mathrm{CA}_{\mathrm{i}}, \mathrm{CB}_{\mathrm{i}}, \mathrm{CO}_{\mathrm{i}}\right)$ were obtained from 3D NCACO and NCACB spectra. The assignment strategy is based on the principle that cross-peaks in the 3D CANCO spectrum correlate the resonance frequencies of three connected spins, two of which were identified in the previous step, and complemented by a new frequency of a further spin system. This strategy works in principle in both directions. 
Table 1 Experimental parameters

\begin{tabular}{|c|c|c|c|c|c|c|}
\hline Experiment & NCOCA & NCOCACB & $\mathrm{N}(\mathrm{co}) \mathrm{CACB}$ & NCACO & NCACB & CANCO \\
\hline $\begin{array}{l}{ }^{1} \mathrm{H} \text { Larmor freq. } \\
\text { (MHz) }\end{array}$ & 800 & 800 & 850 & 800 & 800 & 800 \\
\hline MAS rate $(\mathrm{kHz})$ & 20 & 20 & 21 & 20 & 20 & 20 \\
\hline Initial transfer & $\mathrm{H}-\mathrm{N}, \mathrm{CP}$ & $\mathrm{H}-\mathrm{N}, \mathrm{CP}$ & $\mathrm{H}-\mathrm{N}, \mathrm{CP}$ & $\mathrm{H}-\mathrm{N}, \mathrm{CP}$ & $\mathrm{H}-\mathrm{N}, \mathrm{CP}$ & $\mathrm{H}-\mathrm{C}, \mathrm{CP}$ \\
\hline Field $(\mathrm{kHz})-\mathrm{H}$ & 54.4 & 54.4 & 57.1 & 54.4 & 54.4 & 77.7 \\
\hline Field $(\mathrm{kHz})-\mathrm{X}$ & 30.1 & 30.1 & 33.3 & 30.1 & 30.1 & 50.0 \\
\hline Shape & ramp $100-80 \mathrm{H}$ & ramp100-80 H & ramp100-80 H & ramp100-80 H & ramp100-80 H & ramp $100-80 \mathrm{H}$ \\
\hline${ }^{13} \mathrm{C}$ carrier $(\mathrm{ppm})$ & - & - & - & - & - & 56.8 \\
\hline Time (ms) & 0.34 & 0.34 & 0.34 & 0.34 & 0.34 & 0.19 \\
\hline Transfer 2 & $\begin{array}{l}\text { N-CO, } \\
\text { SPECIFIC-CP }\end{array}$ & $\begin{array}{l}\text { N-CO, } \\
\text { SPECIFIC-CP }\end{array}$ & $\begin{array}{l}\text { N-CO, } \\
\text { SPECIFIC-CP }\end{array}$ & $\begin{array}{l}\text { N-CA, } \\
\text { SPECIFIC-CP }\end{array}$ & $\begin{array}{l}\text { N-CA, } \\
\text { SPECIFIC-CP }\end{array}$ & $\begin{array}{l}\text { CA-N, } \\
\text { SPECIFIC-CP }\end{array}$ \\
\hline Field $(\mathrm{kHz})-\mathrm{H}$ & 73.0 & 73.0 & 80.6 & 73.8 & 73.8 & 73.8 \\
\hline Field $(\mathrm{kHz})-\mathrm{N}$ & 13.7 & 13.7 & 14.0 & 13.3 & 13.3 & 13.3 \\
\hline Field (kHz)-C & 7.7 & 7.7 & 9.1 & 7.6 & 7.6 & 7.6 \\
\hline Shape & ramp100-80 N & ramp100-80 N & ramp100-80 N & ramp100-80 C & ramp100-80 C & ramp80-100 C \\
\hline${ }^{13} \mathrm{C}$ carrier $(\mathrm{ppm})$ & 176.8 & 176.8 & 176.8 & 56.8 & 56.8 & 56.8 \\
\hline Time (ms) & 4.1 & 4.1 & 4.1 & 3.9 & 3.9 & 3.9 \\
\hline Transfer 3 & $\mathrm{CO}-\mathrm{CA}, \mathrm{BSH}-\mathrm{CP}$ & $\mathrm{CO}-\mathrm{CA}, \mathrm{BSH}-\mathrm{CP}$ & $\mathrm{CO}-\mathrm{CA}, \mathrm{BSH}-\mathrm{CP}$ & CA-CO, BSH-CP & CA-CB, DREAM & $\begin{array}{l}\mathrm{N}-\mathrm{CO}, \\
\text { SPECIFIC-CP }\end{array}$ \\
\hline Trim pulse & $3.45 \mu \mathrm{s} / 50 \mathrm{kHz}$ & $3.45 \mu \mathrm{s} / 50 \mathrm{kHz}$ & $3.0 \mu \mathrm{s} / 55.5 \mathrm{kHz}$ & - & - & - \\
\hline Field $(\mathrm{kHz})-\mathrm{H}$ & 75.5 & 75.5 & 80.6 & 75.5 & 73.8 & 73.0 \\
\hline Field $(\mathrm{kHz})-\mathrm{N}$ & - & - & - & - & - & 13.7 \\
\hline Field $(\mathrm{kHz})-\mathrm{C}$ & 14.2 & 14.2 & 13.8 & 14.6 & 11.1 & 7.7 \\
\hline Shape & ramp100-80 C & ramp100-80 C & ramp100-80 C & ramp100-80 C & ramp80-100 C & ramp100-80 N \\
\hline${ }^{13} \mathrm{C}$ carrier $(\mathrm{ppm})$ & 56.8 & 56.8 & 57.2 & 56.8 & 56.8 & 176.8 \\
\hline Time (ms) & 3.75 & 3.75 & 4.0 & 4.2 & 1.7 & 4.1 \\
\hline Trim pulse & - & - & - & $5 \mu \mathrm{s} / 50 \mathrm{kHz}$ & - & - \\
\hline Transfer 4 & - & CA-CB, DREAM & CA-CB, DREAM & - & - & - \\
\hline Field $(\mathrm{kHz})-\mathrm{H}$ & - & 73.8 & 80.6 & - & - & - \\
\hline Field $(\mathrm{kHz})-\mathrm{C}$ & - & 11.1 & 10.6 & - & - & - \\
\hline Shape & - & ramp80-100 C & ramp80-100 C & - & - & - \\
\hline${ }^{13} \mathrm{C}$ carrier $(\mathrm{ppm})$ & - & 56.8 & 40.0 & - & - & - \\
\hline Time (ms) & - & 1.7 & 1.7 & - & - & - \\
\hline t1 evolution & $\mathrm{N}$ & $\mathrm{N}$ & $\mathrm{N}$ & $\mathrm{N}$ & $\mathrm{N}$ & CA \\
\hline Field $(\mathrm{kHz})-\mathrm{H}$ & 78.2 & 78.2 & 80.6 & 78.2 & 78.2 & 78.2 \\
\hline $180^{\circ}$ pulse & $\mathrm{C}$ & $\mathrm{C}$ & $\mathrm{C}$ & $\mathrm{C}$ & $\mathrm{C}$ & $\mathrm{N}$ \\
\hline $\begin{array}{l}\text { Sweep width } \\
\quad(\mathrm{kHz})\end{array}$ & 3.5 & 3.5 & 3.4 & 3.5 & 3.5 & 5.2 \\
\hline a.q. time $(\mathrm{ms})$ & 8.00 & 8.00 & 6.96 & 7.14 & 7.14 & 5.00 \\
\hline Increments & 56 & 56 & 48 & 50 & 50 & 52 \\
\hline t2 evolution ${ }^{[a]}$ & $\mathrm{CO}$ & $\mathrm{CO}$ & $\mathrm{CA}$ & $\mathrm{CA}$ & CA & $\mathrm{N}$ \\
\hline Field $(\mathrm{kHz})-\mathrm{H}$ & 78.2 & 78.2 & 80.6 & 78.2 & 78.2 & 78.2 \\
\hline $180^{\circ}$ pulse & $\mathrm{N}$ & $\mathrm{N}$ & $\mathrm{N}$ & $\mathrm{N}$ & $\mathrm{N}$ & $\mathrm{C}$ \\
\hline $\begin{array}{l}\text { Sweep width } \\
(\mathrm{kHz})\end{array}$ & 2.8 & 2.8 & 5.5 & 5.2 & 5.2 & 3.5 \\
\hline a.q. time (ms) & 5.71 & 5.71 & 5.03 & 5.00 & 5.00 & 7.14 \\
\hline Increments & 32 & 32 & 56 & 52 & 52 & 50 \\
\hline Detection (t3) & $\mathrm{CO}, \mathrm{CA}$ & $\mathrm{CO}, \mathrm{CA}, \mathrm{CB}$ & $\mathrm{CO}, \mathrm{CA}, \mathrm{CB}$ & $\mathrm{CO}, \mathrm{CA}$ & $\mathrm{CA}, \mathrm{CB}$ & $\mathrm{CO}$ \\
\hline Field $(\mathrm{kHz})-\mathrm{H}$ & 78.2 & 78.2 & 80.6 & 78.2 & 78.2 & 78.2 \\
\hline
\end{tabular}


Table 1 continued

\begin{tabular}{|c|c|c|c|c|c|c|}
\hline Experiment & NCOCA & NCOCACB & $\mathrm{N}(\mathrm{co}) \mathrm{CACB}$ & $\mathrm{NCACO}$ & NCACB & CANCO \\
\hline $\begin{array}{l}\text { Sweep width } \\
(\mathrm{kHz})\end{array}$ & 59.5 & 59.5 & 64.1 & 59.5 & 59.5 & 59.5 \\
\hline a.q. time (ms) & 8.94 & 7.98 & 7.94 & 8.94 & 8.94 & 8.94 \\
\hline Increments & 1,064 & 950 & 1,018 & 1,064 & 1,064 & 1,064 \\
\hline Pre-scan delay (s) & 3.0 & 3.0 & 3.0 & 3.0 & 3.0 & 3.0 \\
\hline Number of scans & 16 & 32 & 16 & 16 & 16 & 8 \\
\hline $\begin{array}{l}\text { Measurement time } \\
\text { (h) }\end{array}$ & 24.2 & 48.4 & 36.3 & 35.0 & 35.0 & 17.5 \\
\hline
\end{tabular}

Fig. 3 Strip plot of different 3D experiments showing the sequential walk for the amino acid stretch D58-I61. NCOCACB spectra are presented in red (positive signals) and blue (negative signals), CANCO spectra in magenta, NCACO in orange and NCACB in purple (positive signals) and green (negative signals). Solid lines represent the assignments used in the sequential walk

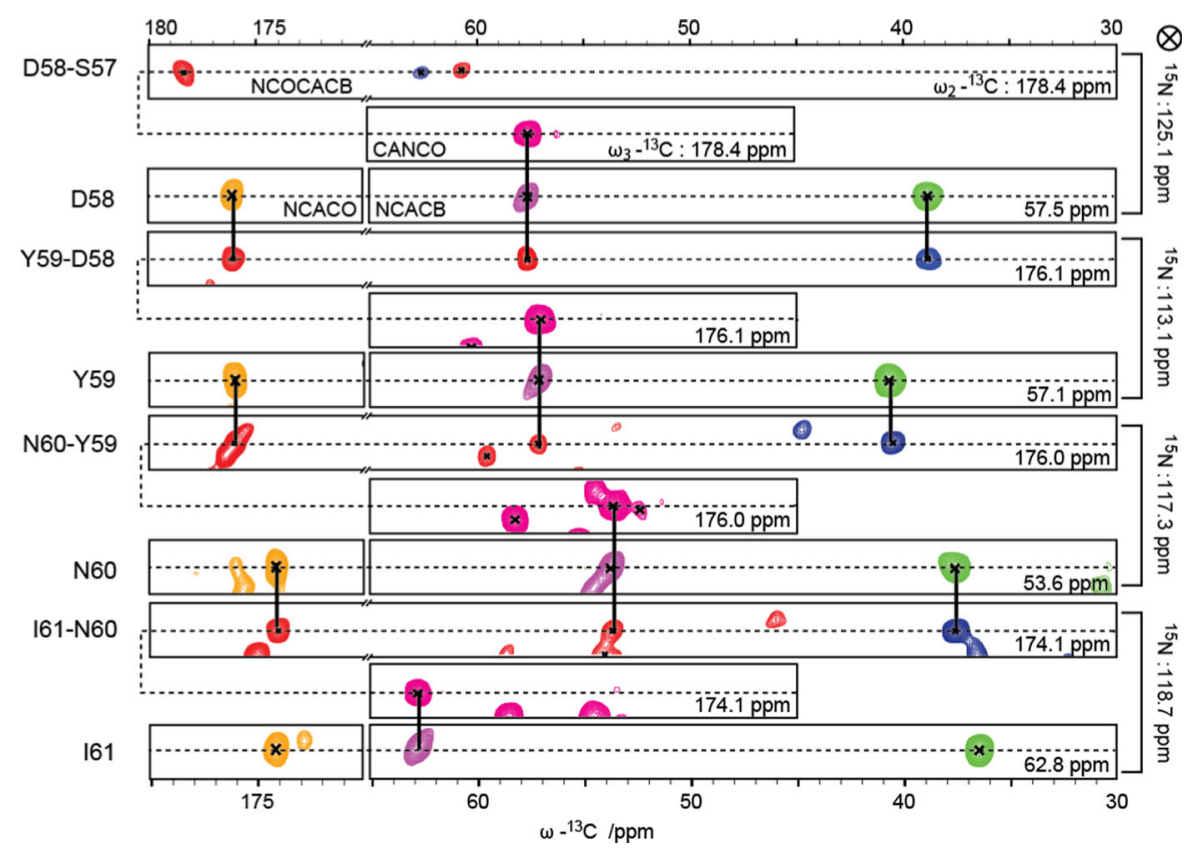

are presented in Supporting Table 1. Similar to previous ssNMR investigations on PEG-precipitated ubiquitin (Seidel et al. 2005; Chevelkov et al. 2013b), peak doubling could be observed for some regions in the MPD-crystallized material studied here as well. The last six C-terminal residues cannot be assigned due to dynamic disorder. In previous studies of MPD-crystallized ubiquitin by ssNMR, only a single set of resonances was reported (Igumenova et al. 2004; Schubert et al. 2006). One of the reasons for this may lie in the slightly different crystallization conditions used. McDermott and coworkers utilized $60 \%$ MPD, $20 \mathrm{mM}$ citrate buffer, at $\mathrm{pH}$ 4.0-4.2. In contrast, we used $40 \% \mathrm{MPD}, 0.2 \mathrm{M} \mathrm{CdCl}_{2}$, at $\mathrm{pH}$ 6.5. Furthermore, we note that some of the doubled resonances differ in intensity and can only be observed in spectra with very high $\mathrm{S} / \mathrm{N}$.

In conclusion, we have recorded a complete set of highquality 3D spectra required for unambiguous resonance assignment of the backbone resonances. Due to the

Almost all of the backbone resonances were assigned from Q2 to V70 in the 3D spectra, and the chemical shifts 
Fig. 4 Strip plot of different 3D experiments showing the sequential walk for the amino acid stretch E24-I30. All the spectra are presented in red (positive signals) and blue (negative signals)

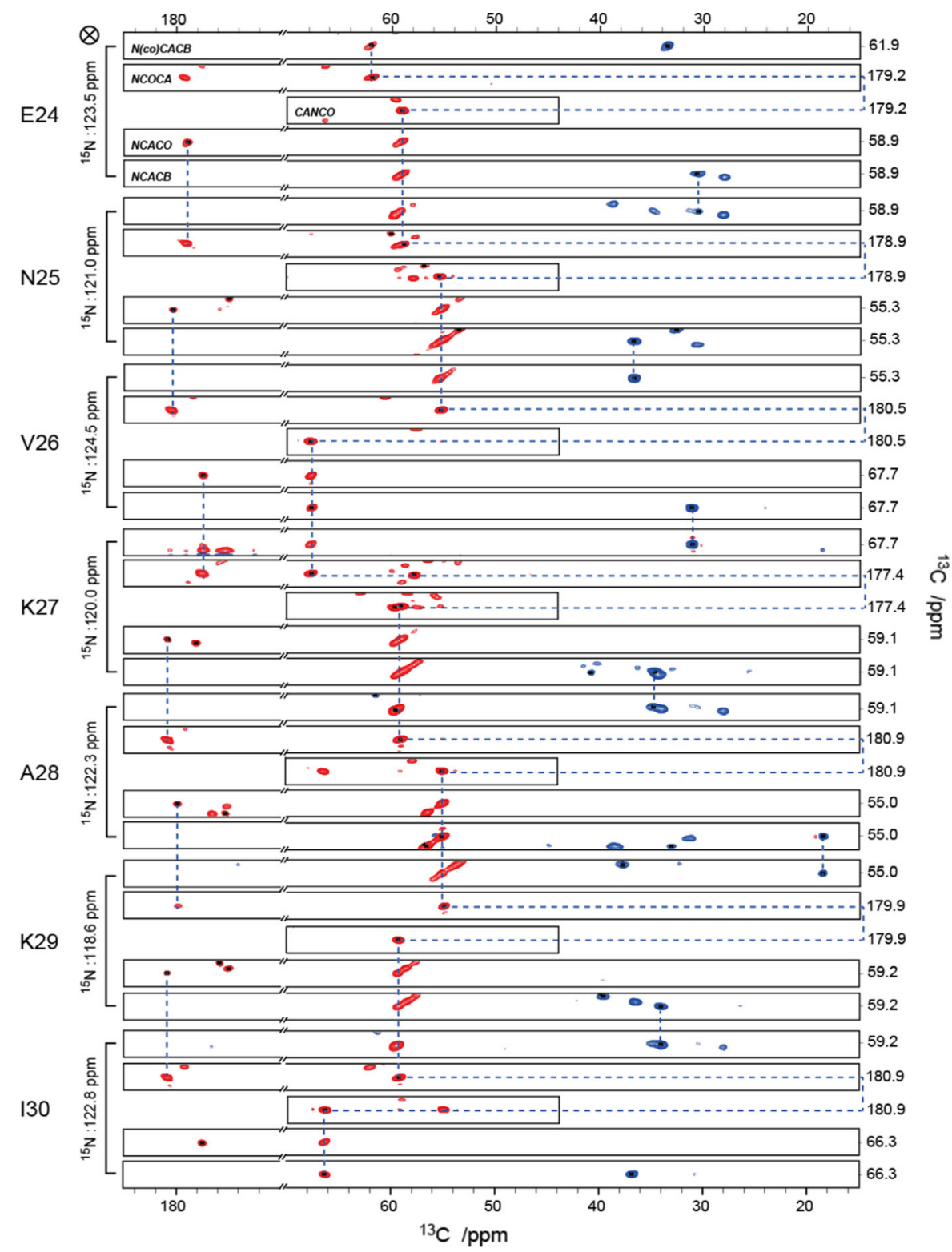

excellent transfer efficiency provided by $\mathrm{BSH}-\mathrm{CP}$, the complete set could be recorded in a short time frame with high sensitivity and resolution.

\section{Materials and methods}

Sample preparation

Uniformly $\left[{ }^{13} \mathrm{C},{ }^{15} \mathrm{~N}\right]$-labeled ubiquitin was expressed and purified as described earlier (Lazar et al. 1997). Around $15 \mathrm{mg}$ of MPD-crystallized material was transferred into a $3.2 \mathrm{~mm}$ rotor.
Solid-state NMR experiments

All spectra with the exception of the 3D N(co)CACB spectrum were conducted on a Bruker Avance II $800 \mathrm{MHz}$ standard-bore spectrometer equipped with a commercial (Bruker Biospin) $3.2 \mathrm{~mm}\left({ }^{1} \mathrm{H},{ }^{13} \mathrm{C},{ }^{15} \mathrm{~N}\right)$ triple-resonance probe. The $\mathrm{N}(\mathrm{co}) \mathrm{CACB}$ spectrum was measured on a Bruker Avance III $850 \mathrm{MHz}$ wide-bore spectrometer equipped with a commercial (Bruker Biospin) $3.2 \mathrm{~mm}\left({ }^{1} \mathrm{H}\right.$, $\mathrm{X}, \mathrm{Y}$ ) triple-resonance probe. MAS rates of $20 \mathrm{kHz}$ and $21 \mathrm{kHz}$ were employed for experiments at $800 \mathrm{MHz}$ and $850 \mathrm{MHz}$, respectively. The probe temperature was set to $-25{ }^{\circ} \mathrm{C}$ resulting in an effective sample temperature of 
about $0 \pm 2{ }^{\circ} \mathrm{C}$ as measured by the temperature-dependent water proton resonance (Boeckmann et al. 2009). Typical radiofrequency strength of proton, carbon and nitrogen hard pulses was $83.3,50$ and $35.7 \mathrm{kHz}$, respectively. SPINAL-64 heteronuclear decoupling during isotropic chemical shift evolution was applied on the proton channel with an RF strength of $78 \mathrm{kHz}$. CW decoupling with an RF strength around $75 \mathrm{kHz}$ was applied during SPECIFIC-CP, $\mathrm{BSH}-\mathrm{CP}$ and DREAM recoupling. Detailed parameters for all 3D experiments are supplied in Table 1.

Acknowledgments We thank Karin Giller and Brigitta Angerstein for expert technical assistance. This work was supported by the Max Planck Society, the DFG (Emmy Noether Fellowship to A. L.), and the European Union Seventh Framework Program under Grant Agreement 261863 (Bio-NMR). C. S. acknowledges funding from the MPG-CAS Joint Doctoral Promotion Programme. B. H. acknowledges EMBO for a long-term postdoctoral fellowship.

\section{References}

Baldus M, Petkova AT, Herzfeld J, Griffin RG (1998) Cross polarization in the tilted frame: assignment and spectral simplification in heteronuclear spin systems. Mol Phys 95(6): 1197-1207. doi:10.1080/002689798166215

Boeckmann A, Gardiennet C, Verel R, Hunkeler A, Loquet A, Pintacuda G, Emsley L, Meier BH, Lesage A (2009) Characterization of different water pools in solid-state NMR protein samples. J Biomol NMR 45(3):319-327. doi:10.1007/s10858009-9374-3

Chevelkov V, Giller K, Becker S, Lange A (2013a) Efficient CO-CA transfer in highly deuterated proteins by band-selective homonuclear cross-polarization. J Magn Reson 230:205-211. doi:10. 1016/j.jmr.2013.02.021

Chevelkov V, Shi C, Fasshuber HK, Becker S, Lange A (2013b) Efficient band-selective homonuclear CO-CA cross-polarization in protonated proteins. J Biomol NMR 56(4):303-311. doi:10. 1007/s10858-013-9767-1

Demers J-P, Chevelkov V, Lange A (2011) Progress in correlation spectroscopy at ultra-fast magic-angle spinning: basic building blocks and complex experiments for the study of protein structure and dynamics. Solid State Nucl Magn Reson 40(3):101-113. doi:10.1016/j.ssnmr.2011.07.002

Dusold S, Sebald A (2000) Dipolar recoupling under magic-angle spinning conditions. Annu Rep NMR Spectrosc 41(41):185-264. doi:10.1016/s0066-4103(00)41010-0

Fung BM, Khitrin AK, Ermolaev K (2000) An improved broadband decoupling sequence for liquid crystals and solids. J Magn Reson 142(1):97-101

Goldbourt A (2013) Biomolecular magic-angle spinning solid-state NMR: recent methods and applications. Curr Opin Biotechnol 24(4):705-715. doi:10.1016/j.copbio.2013.02.010

Habenstein B, Wasmer C, Bousset L, Sourigues Y, Schuetz A, Loquet A, Meier BH, Melki R, Boeckmann A (2011) Extensive de novo solid-state NMR assignments of the $33 \mathrm{kDa}$ C-terminal domain of the Ure2 prion. J Biomol NMR 51(3):235-243. doi:10.1007/ s10858-011-9530-4

Hodgkinson P, Emsley L (1999) The accuracy of distance measurements in solid-state NMR. J Magn Reson 139(1):46-59. doi:10. 1006/jmre 1999.1759
Hong M, Zhang Y, Hu F (2012) Membrane Protein Structure and Dynamics from NMR Spectroscopy. In: Johnson MA, Martinez TJ (eds) Annual review of physical chemistry, vol 63, pp 1-24. doi:10.1146/annurev-physchem-032511-143731

Igumenova TI, McDermott AE, Zilm KW, Martin RW, Paulson EK, Wand AJ (2004) Assignments of carbon NMR resonances for microcrystalline ubiquitin. J Am Chem Soc 126(21):6720-6727. doi:10.1021/ja030547o

Jehle S, Rajagopal P, Bardiaux B, Markovic S, Kuehne R, Stout JR, Higman VA, Klevit RE, van Rossum B-J, Oschkinat H (2010) Solid-state NMR and SAXS studies provide a structural basis for the activation of alpha B-crystallin oligomers. Nat Struct Mol Biol 17(9):1037-1042. doi:10.1038/nsmb.1891

Knight MJ, Pell AJ, Bertini I, Felli IC, Gonnelli L, Pierattelli R, Herrmann T, Emsley L, Pintacuda G (2012) Structure and backbone dynamics of a microcrystalline metalloprotein by solid-state NMR. Proc Natl Acad Sci USA 109(28): 11095-11100. doi:10.1073/pnas.1204515109

Laage S, Marchetti A, Sein J, Pierattelli R, Sass HJ, Grzesiek S, Lesage A, Pintacuda G, Emsley L (2008) Band-Selective ${ }^{1} \mathrm{H}-{ }^{13} \mathrm{C}$ Cross-polarization in fast magic angle spinning solid-state NMR spectroscopy. J Am Chem Soc 130(51):17216-17217. doi:10. $1021 / \mathrm{ja} 805926 \mathrm{~d}$

Lazar GA, Desjarlais JR, Handel TM (1997) De novo design of the hydrophobic core of ubiquitin. Protein Sci 6(6):1167-1178

Loquet A, Sgourakis NG, Gupta R, Giller K, Riedel D, Goosmann C, Griesinger C, Kolbe M, Baker D, Becker S, Lange A (2012) Atomic model of the type III secretion system needle. Nature 486(7402):276-279. doi:10.1038/nature 11079

Mainz A, Religa TL, Sprangers R, Linser R, Kay LE, Reif B (2013) NMR spectroscopy of soluble protein complexes at one megadalton and beyond. Angew Chem Int Ed Engl 52(33): 8746-8751. doi:10.1002/anie.201301215

Morcombe CR, Gaponenko V, Byrd RA, Zilm KW (2004) Diluting abundant spins by isotope edited radio frequency field assisted diffusion. J Am Chem Soc 126(23):7196-7197. doi:10.1021/ ja047919t

Pauli J, Baldus M, van Rossum B, de Groot H, Oschkinat H (2001) Backbone and side-chain ${ }^{13} \mathrm{C}$ and ${ }^{15} \mathrm{~N}$ signal assignments of the alpha-spectrin $\mathrm{SH} 3$ domain by magic angle spinning solid-state NMR at 17.6 tesla. ChemBioChem 2(4):272-281. doi:10.1002/ 1439-7633(20010401)2:4<272:aid-cbic272>3.0.co;2-2

Scholz I, Huber M, Manolikas T, Meier BH, Ernst M (2008) MIRROR recoupling and its application to spin diffusion under fast magic-angle spinning. Chem Phys Lett 460(1-3):278-283. doi:10.1016/j.cplett.2008.05.058

Schubert M, Manolikas T, Rogowski M, Meier BH (2006) Solid-state NMR spectroscopy of $10 \%$ C-13 labeled ubiquitin: spectral simplification and stereospecific assignment of isopropyl groups. J Biomol NMR 35(3):167-173. doi:10.1007/s10858-006-9025-x

Schuetz A, Wasmer C, Habenstein B, Verel R, Greenwald J, Riek R, Boeckmann A, Meier BH (2010) Protocols for the sequential solid-state NMR spectroscopic assignment of a uniformly labeled $25 \mathrm{kDa}$ protein: HET-s(1-227). ChemBioChem 11(11): 1543-1551. doi:10.1002/cbic.201000124

Seidel K, Etzkorn M, Heise H, Becker S, Baldus M (2005) Highresolution solid-state NMR studies on uniformly ${ }^{13} \mathrm{C},{ }^{15} \mathrm{~N}$ labeled ubiquitin. ChemBioChem 6(9):1638-1647. doi:10.1002/ cbic. 200500085

Sengupta I, Nadaud PS, Helmus JJ, Schwieters CD, Jaroniec CP (2012) Protein fold determined by paramagnetic magic-angle spinning solid-state NMR spectroscopy. Nat Chem 4(5):410 417. doi: $10.1038 /$ nchem. 1299

Shaka AJ, Keeler J, Frenkiel T, Freeman R (1983) An improved sequence for broad-band decoupling-WALTZ-16. J Magn Reson 52(2):335-338 
Shi L, Ahmed MAM, Zhang W, Whited G, Brown LS, Ladizhansky V (2009) Three-dimensional solid-state NMR study of a sevenhelical integral membrane proton pump-structural insights. J Mol Biol 386(4):1078-1093. doi:10.1016/j.jmb.2009.01.011

Sperling LJ, Berthold DA, Sasser TL, Jeisy-Scott V, Rienstra CM (2010) Assignment strategies for large proteins by magic-angle spinning NMR: the $21-\mathrm{kDa}$ disulfide-bond-forming enzyme DsbA. J Mol Biol 399(2):268-282. doi:10.1016/j.jmb.2010.04. 012

Takegoshi K, Nakamura S, Terao T (2001) C-13-H-1 dipolar-assisted rotational resonance in magic-angle spinning NMR. Chem Phys Lett 344(5-6):631-637. doi:10.1016/s0009-2614(01)00791-6

Tycko R (2011) Solid-state NMR studies of amyloid fibril structure. In: Leone SR, Cremer PS, Groves JT, Johnson MA (eds) Annual review of physical chemistry, vol 62, pp 279-299. doi:10.1146/ annurev-physchem-032210-103539
Ullrich SJ, Hellmich UA, Ullrich S, Glaubitz C (2011) Interfacial enzyme kinetics of a membrane bound kinase analyzed by realtime MAS-NMR. Nat Chem Biol 7(5):263-270. doi:10.1038/ nchembio. 543

Verel R, Ernst M, Meier BH (2001) Adiabatic dipolar recoupling in solid-state NMR: the DREAM scheme. J Magn Reson 150(1):81-99. doi:10.1006/jmre 2001.2310

Vijayan V, Demers J-P, Biernat J, Mandelkow E, Becker S, Lange A (2009) Low-power solid-state NMR experiments for resonance assignment under fast magic-angle spinning. ChemPhysChem 10(13):2205-2208. doi:10.1002/cphc.200900439

Wasmer C, Lange A, Van Melckebeke H, Siemer AB, Riek R, Meier BH (2008) Amyloid fibrils of the HET-s(218-289) prion form a beta solenoid with a triangular hydrophobic core. Science 319(5869):1523-1526. doi:10.1126/science.1151839 